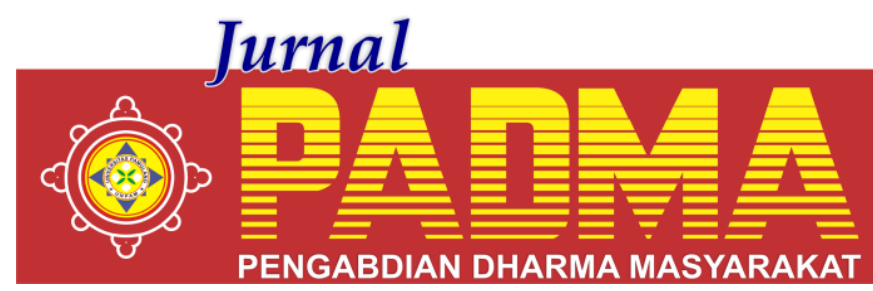

VOLUME 1, NOMOR 2, APRIL 2021

\title{
SOSIALISASI BISNIS DIGITAL PADA SISWA-SISWI SMK TECHNO MEDIA
}

\author{
${ }^{1}$ Syifa Ayu Fauziah, ${ }^{2}$ Aulia Fahmi Mahendra, ${ }^{3}$ Mairlef Alpha Larien, ${ }^{4}$ Yuliasari, ${ }^{5}$ Wahyu \\ Herdiansah , 6*Aidil Amin Effendy \\ Universitas Pamulang, Tangerang Selatan, Banten, Indonesia \\ *aidil00967@unpam.ac.id
}

\begin{abstract}
Abstrak
Perkembangan teknologi dan ilmu pengetahuan saat ini mendorong bidang ilmu manajemen untuk terus melakukan penyempurnaan dari segi produktivitas, kreatifitas dan efektivitas. Tujuan yang ingin dicapai dalam pengabdian ini adalah menambah wawasan masyarakat tentang bisnis digital dan memudahkan masyarakat melaksanakan usaha berbasis dana rendah yang efektif dan efisien sesuai dengan kebutuhan yang dibutuhkan oleh kalangan remaja bahkan dewasa yang ingin memulai usaha. Pengabdian ini diharapkan dapat memberikan kontribusi kepada usaha kecil agar dapat menambah penghasilan dengan sistem yang mudah. Hasil akhir dari pengabdian ini adalah penggunaan sistem reseller dalam situs E-Commerce pada usaha kecil.
\end{abstract}

Kata Kunci : Bisnis Digital, Reseller, Modal

The development of technology and science today encourages the field of management to continue to make improvements in terms of productivity, creativity and effectiveness. The goal to be achieved $n$ this service is to increase public insight about digital business and make it easier for people to carry out low-fundbased businesses that are effective and efficient according to the needs needed by teenagers and even adults who want to start a business. This service is expected to contribute to small businesses so that they can increase their income with an easy system. The end result of this sevice is the use of a reseller system on the ECommerce site for small businesses.

Keywords: Digital Business, Reseller, Capital.

\section{PENDAHULUAN}

Bisnis digital adalah suatu jenis bisnis jasa yang memanfaatkan kecanggihan teknologi ketika menciptakan sebuah produk ataupun memasarkannya. Berbeda dengan yang kita pahami sebelumnya, bisnis digital tidak semata terkait dengan penjualan produk tanpa wujud saja, seperti perangkat lunak komputer (software). Bisnis digital juga tidak hanya tentang produk fisik yang dikemas dalam bentuk digital seperti ebook (buku elektronik). Dalam berbisnis dibutuhkan modal yang cukup, Modal adalah suatu hal yang tidak bisa dipisahkan dalam berbisnis atau berusaha, berinvestasi, dan berbagai aktivitas lain yang memiliki tujuan untuk memperoleh keuntungan maupun penghasilan. Secara garis besar, pengertian modal adalah sekumpulan uang ataupun barang yang bisa digunakan untuk dasar dalam melakukan suatu pekerjaan atau usaha. Jadi, pengertian modal adalah suatu aset utama perusahaan dalam menjalankan bisnis yang umumnya berbentuk dana, aset, atau utang. Dengan begitu, maka proses produksi hingga pemasaran perusahaan bisa berjalan dengan lancar.

Faktor utama yang menghambat jalan awal bisnis adalah modal. Banyak kegagalan bisnis yang disebabkan oleh modal. Modal merupakan hal penting bagi bisnis yang akan dibangun. Kadang kegagalan bisnis terjadi pada sedikitnya modal yang dimiliki. Bila modal cukup bisnis bisa lebih maksimal dijalankan namun bila modal dalam berbisnis tersebut kurang tentu saja hal ini bisa menjadi penghalang bisnis.

Adapun solusi yang diusulkan atau ditawarkan dalam kegiatan PKM ini adalah (1) Pengenalan dan pemberian pemahaman kepada masyarakat terhadap bisnis reseller dari kami mahasiswa dan dosen, juga dari ahli yang kami hadirkan sebagai pembicara; (2) Pengenalan dan pemberian pemahaman 
dilakukan untuk menambah wawasan masyarakat tentan bisnis digital dan hal-hal lainnya. (3) Simulasi dan pemberian gambaran tentang alur dari bisnis digital dan reseller. Sehingga masyarakat mampu membayangkan prospek bisnis kedepannya, dengan analisa masing-masing dan mempraktekkannya sendiri.;

Kegiatan Pengabdian Masyarakat merupakan salah satu bagian dari Tri Dharma Perguruan Tinggi. Tujuan Pengabdian Kepada Masyarakat: (1) menciptakan inovasi teknologi untuk mendorong pembangunan ekonomi Indonesia dengan melakukan komersialisasi hasil penelitian; (2) memberikan solusi berdasarkan kajian akademik atas kebutuhan, tantangan, atau persoalan yang dihadapi masyarakat, baik secara langsung maupun tidak langsung; (3) melakukan kegiatan yang mampu mengentaskan masyarakat tersisih (preferential option for the poor) pada semua strata, yaitu masyarakat yang tersisih secara ekonomi, politik, sosial, dan budaya; (4) melakukan alih teknologi, ilmu, dan seni kepada masyarakat untuk pengembangan martabat manusia dan kelestarian sumber daya alam.

Drs. Moekijat ( 2000 : 63 ) Ada banyak perumusan yang berlainan mengenai modal, biasanya modal dianggap terdiri dari uang tunai , kredit, hak membuat dan menjual sesuatu (paten), mesin-mesin dan gedunggedung. Akan tetapi sering istilah tersebut dipergunakan untuk menyatakan hak milik total yang terdiri atas jumlah yang ditanam, surplus dan keuntungan-keuntungan yang tidak dibagi."

Kita bisa menyimpulkan sendiri tentang pengertian modal, yaitu aset baik berupa barang-barang atau dana yang di jadikan sebagai pokok menjalankan sebuah usaha atau bisnis. Itu artinya jika kita bisa mengatur dana modal dengan baik, maka kita juga akan mampu membangun usaha lebih baik, karena sejatinya modal adalah pondasi dalam menjalankan usaha.

Reseller adalah orang menjual kembali produk dari pihak supplier kepada konsumen, untuk menjadi seorang reseller kita tidak harus mengeluarkan modal sendiri, dan membeli produk langsung kepada supplier. Reseller adalah sebuah model bisnis dimana penjual tidak harus mempunyai stok ketika bertransaksi dengan pelanggan, Pada umumnya keuntungan yang dipakai oleh para penjual retail adalah pada kisaran 20\% hingga 30\% dari harga beli, bahkan ada juga yang lebih dari 50\%.

\section{METODE}

Mekanisme pelaksanaan kegiatan Pengabdian mandiri meliputi tahapan berikut: (1) Pembentukan kelompok mahasiswa, (2) Diskusi dengan dosen pembimbing, (3) Konsultasi dan negoisasi dengan Mitra pengabdian, (4) Musyawarah dalam menentukan pola dan konsep program, (5) Penyiapan alat dan bahan untuk kegiatan Pengabdian. Materi persiapan dan pembekalan terhadap Mahasiswa pengabdi mencakup: (1) Sesi musyawarah /aproach; (2) Fungsi Dosen pembimbing dalam Pengabdian oleh ketua kelompok; (4) Panduan dan pelaksanaan program Pengabdian; (5) Kesediaan kepala sekolah dalam sarana dan prasarana kegiatan didalam penerimaan mahasiswa pengabdi; (6) Peninjauan peserta, lokasi dan program kerja yang dipersiapkan.

Persiapan materi kegiatan yang akan dikerjakan serta teknik pelaksanaan dan alokasi waktu, dengan perancangan time schedule kegiatan. Mekanisme pelaksanaan dalam bentuk metode yang akan digunakan dalam pembekalan pengetahuan khususnya pengetahuan mengenai bisnis digital.

\section{BAHAN DAN ALAT YANG DIGUNAKAN}

Bahan dan alat yang digunakan dalam program pengabdian ini adalah sebagai berikut:

1. Modul dengan topik "Sosialisasi Bisnis Digital" sebagai media pembelajaran

2. Proyektor

3. Laptop dan Smartphone

4. Internet

5. Software Pendukung

\section{HASIL DAN PEMBAHASAN}

Dalam hal ini sasaran kegiatan pengabdian adalah pengenalan bisnis digital. Secara umum, sasaran kegiatan pengabdian ini diperuntukkan bagi semua siswa-siswi, guru serta staff SMK Techno Media. Secara khusus, sasaran kegiatan pengabdian ini adalah semua siswa-siswi SMK Techno Media. Jumlah peserta yang ada di SMK 
Techno Media berjumlah kurang lebih 10 orang dan hampir semua mengikuti pelatihan.

Berikut adalah langkah-langkah menerapkan sistem reselling dalambisnis digital.

1. Langkah pertama jika belum terdaftar pada platform jual beli online, maka buatlah akun terlebih dahulu. Isikan data sesuai dengan gambar dibawah ini kemudian klik daftar dan ikuti instruksi selanjutnya

2. Login ke dalam aplikasi dengan nomor telepon dan kata sandi yang telah terdaftar.

3. Selanjutnya, silahkan cari di Pencarian dengan kata kunci "Open Reseller"

4. Setelah memunculkan hasil, silahkan pilih produk apa yang akan di reselling.

5. Setelah mendapatkan produk, silahkan pasarkan produk tersebut.

6. Jika sudah mendapat pembeli, Reseller dapat memilih untuk memakai satu dari dua sistem yang ada yaitu,

(1) Reseller membeli produk tersebut dan mengirimnya sendiri kepada pembeli, atau (2) Supplier mempacking dan mengirim kepada pembeli atas nama pengirimnya yaitu reseller. Untuk sistem kedua, lebih cenderung menggunakan sistem Dropship

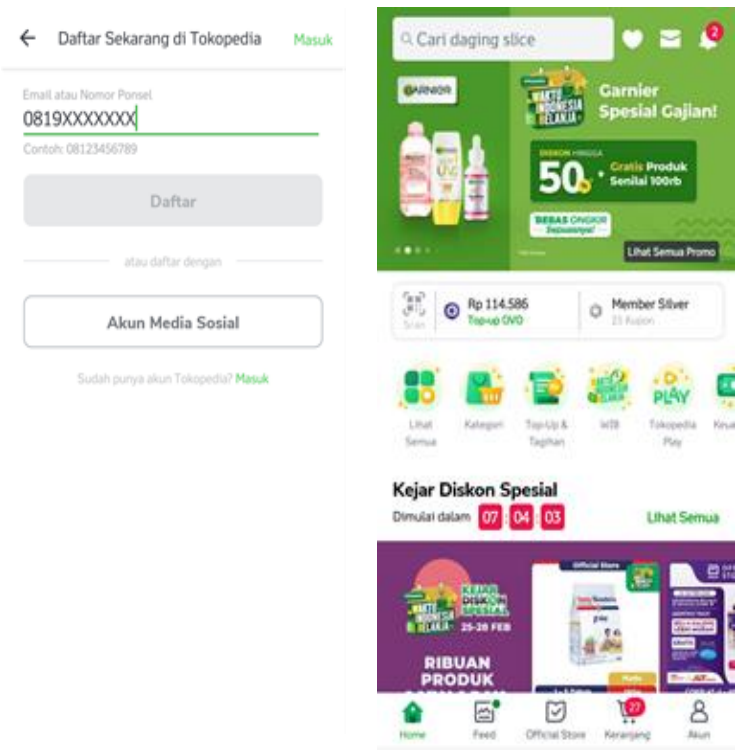

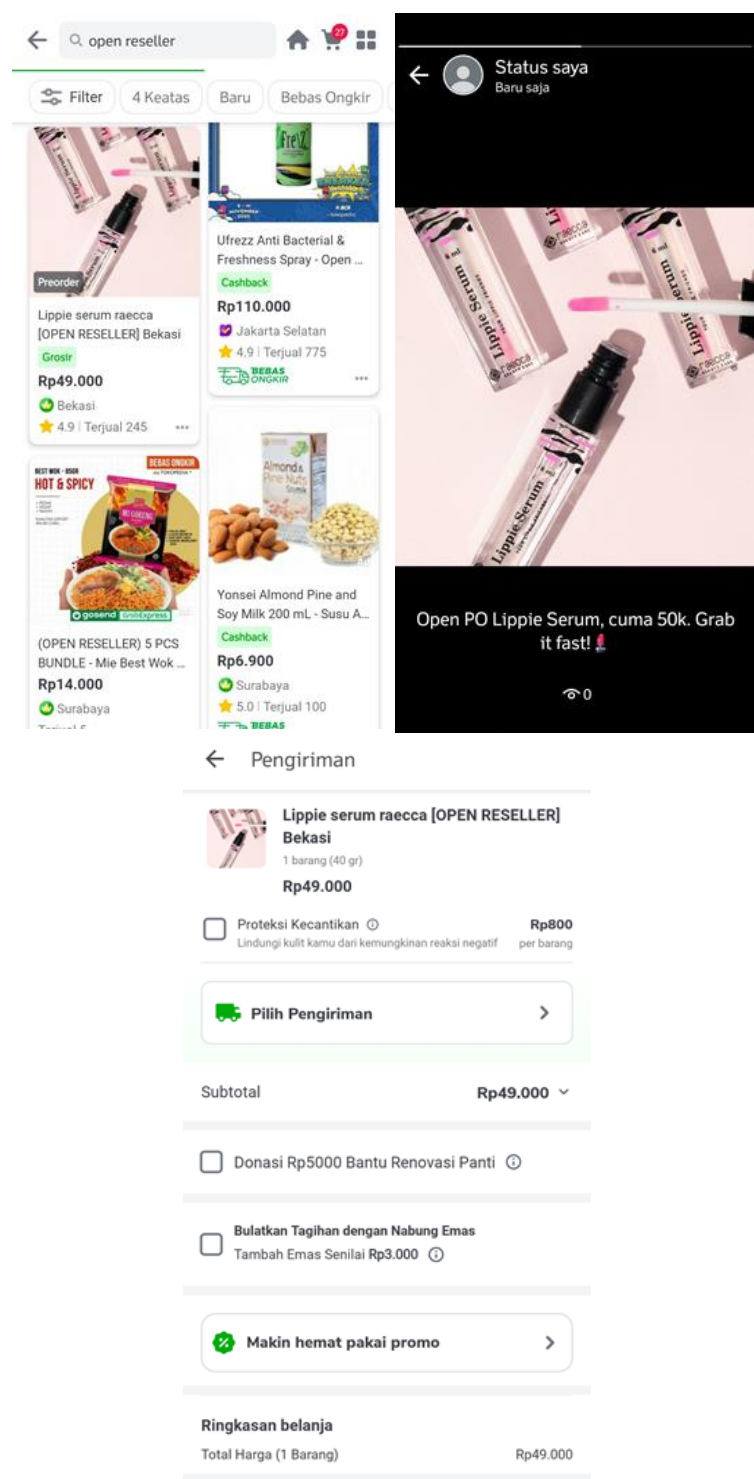

Gambar 1. Toko Online

Hasil dari kegiatan simulasi ini adalah memberikan tambahan wawasan dan bekal tentang bisnis digital yang tidak memerlukan modal. Hal ini menunjukkan bahwa kegiatan simulasi ini sesuai dengan yang diharapkan dan tepat sasaran kepada siswa-siswi SMK Techno Media. Dengan adanya kegiatan ini, semoga kedepannya para siswa dan siswi dapat memanfaatkan dan mengembangkan ilmu tentang bisnis digital.

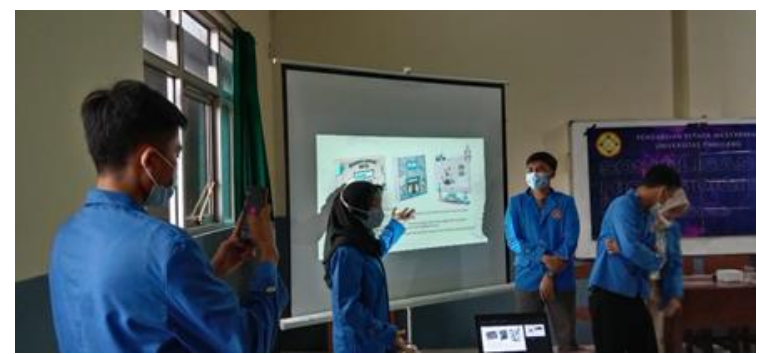




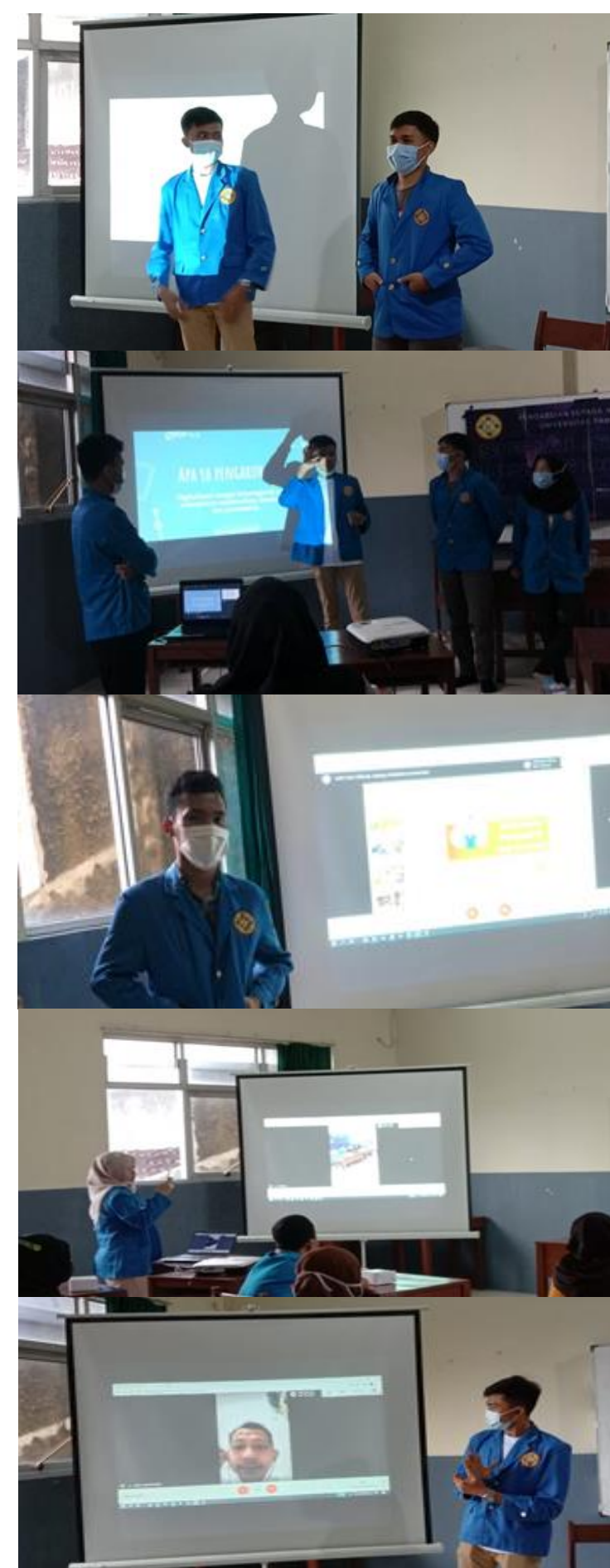

Gambar 2. Kegiatan Selama Pelatihan

Dengan adanya kegiatan pelatihan ini, siswa-siswi dapat mengerti dan paham bahwa bisnis tidak selalu berlandaskan modal. Dengan harapan siswa-siswi dapat memanfaatkan bisnis digital ini dan berkembang menjadi seorang produsen yang dapat membaca dan menganalisa pergerakan traffic data di dunia digital, paham akan tren dan menempatkan strategi yang sesuai untuk bisnis mereka.
Dari kegiatan pengabdian ini juga, siswa-siswi diharap dapat bersaing pada era revolusi industri 4.0, dengan pemahaman tentang bisnis digital yang cukup kuat untuk menghadapi persaingan kerja yang ketat.

\section{PENUTUP \\ Simpulan}

Hasil dari kegiatan pengabdian masyarakat Mahasiswa Universitas Pamulang adalah siswa-siswi mampu paham dan menjalankan bisnis digital sebagai media pendorong ekonomi dalam skala keluarga, lingkungan bahkan daerah.

Dengan kemampuan tersebut, para siswa-siswi diharapkan dapat meningkatkan intelegensi dan wawasan terhadap selukbeluk bisnis digital sehingga dapat menyeimbangi penerapan bisnis itu sendiri

\section{Saran}

Adapun saran yang dapat diajukan adalah sebagai berikut:

1. Siswa-siswi dapat memaksimalkan fiturfitur dalam platform media sosial sehingga lebih paham.

2. Siswa-siswi diharapkan dapat mengembangkan kreatifitas dalam memasarkan produk untuk meningkatkan antusiasme ekosistem dan meningkatkan engagement dalam platform jual beli tersebut.

3. Siswa-siswi harus pandai berinovasi dalam pengkategorian produk dan menyampaikan promosi dalam berbagai platform sehingga jangkauan yang didapat lebih luas dan semakin memenuhi kebutuhan pasar dan tren dalam dunia digital.

4. Siswa-siswi diharap dapat membangkitkan antusiasme dalam mempelajari ilmu tentang bisnis digital

\section{DAFTAR PUSTAKA}

databoks.katadata.co.id, "Jumlah Pengguna Internet di Indonesia Capai 196,7 Juta" \& "Tren Pengguna E-Commerce Terus Tumbuh".

Erlangga, H. (2020). The Challenges of Organizational Communication in the Digital Era. Solid State Technology, 63(4), 1240-1246.

Fiqih Isnawan, Puput Irfansyah, Dwi Dani Apriyani. (2018). Pengoptimalan Cloud 
Storage-Google Drive Sebagai Media Pembelajaran Untuk Guru SMP dan SMA, 01(01), 62-76.

Guruh, M. (2018). Pengaruh Kompetensi Terhadap Kinerja Guru Pada SMK Kartika X-2. JENIUS (Jurnal Ilmiah Manajemen Sumber Daya Manusia), 2(1).

Prof. Vincent Didiek Wiet Aryanto, MBA., Ph.D., dan Dr. Yohan Wismantoro, SE., MM. 2020. Marketing Digital: Solusi Bisnis Masa Kini dan Masa Depan. Jakarta:Kanisius.

Purwanti, Y. (2021). The Influence Of Digital Marketing \& Innovasion On The School Performance. Turkish Journal of Computer and Mathematics Education (TURCOMAT), 12(7), 118-127.
Pusat Data dan Analisa Tempo. 2019. Tren Bisnis Berbasis Digital. Jakarta:Tempo Publishing.

Restituta Ajeng Arjanti \& Reney Lendy Mosal. 2012. StartUp, Indonesia: Inspirasi \& Pelajaran dari Para Pendiri Bisnis Digital. Jakarta:Penerbit Buku Kompas.

Sudiarto, S. (2018). Membangun Motivasi Kerja Guru Dalam Menyiapkan Sumber Daya Manusia Indonesia Yang Berkualitas (Analisis Teori Motivasi Abraham Maslow Di SMK Negeri 57 Jakarta). JENIUS (Jurnal Ilmiah Manajemen Sumber Daya Manusia), $1(3)$.

www.kominfo.go.id, "Data Jumlah Pengguna Internet November 2020 di Indonesia". 